\title{
Two Omissions from The Secret Rose, Stories by W. B. Yeats: a Variorum Edition
}

\section{Warwick Gould}

Upon p. 234 of the above work, the following should be inserted after "who" in 1. 11:

[day who 1905 re-issue of $1904 \mathrm{~T}$ ]

Upon the same page, after 1. 16 (end of item 5), the following should be inserted:

5a. [Note 1908, Vol. viii].

Mr. Bullen has just shown me the fifth volume of this edition of my writings, and I discover that a note to the stories of Red Hanrahan has been forgotten by the printer. That note should have said that I owe thanks to Lady Gregory, who helped me to rewrite the stories of Red Hanrahan in the beautiful country speech of Kiltartan, and nearer to the tradition of the people among whom he, or some likeness of him, drifted and is remembered. - April 14, 1908.

I am grateful to Richard Finneran for pointing out to me the second of these omissions. The first, a punctuational change in a note on the verso of the title page of 1905 reissue of $1904 \mathrm{~T}$, came to light too late for the Cornell University Press to include an errata slip in the published volume. 